\title{
INVESTIGATION OF 11TH GRADE TEACHERS' AND STUDENTS' PERCEPTION AND THE IMPLEMENTATION OF ERT IN TEACHING AND LEARNING IN EFL CONTEXT
}

\author{
T. Paradina', M.H. Santosa ${ }^{2}$, D.P. Ramendra ${ }^{3}$ \\ ${ }^{123}$ English Language Education, Universitas Pendidikan Ganesha, Singaraja \\ e-mail: tiniparadina@gmail.com, mhssantosa@undiksha.ac.id, dewaramendra@yahoo.com
}

This study aimed to analyze grade 11th teachers' and student' perception and the implementation of ERT, and analyzed problems experienced by teachers and students during the teaching and learning process. This research used mix - method design, the quantitative method was conducted to identify the EFL teachers and students' perception, while qualitative method was conducted to identify the implementation of ERT. The questionnaire was carried out by 110 11th grade students in SMKN 2 Bangli and 30 English teachers, the data from the interview were analyzed with guidance of analyzing qualitative data, and in analyzing the checklist, the researcher used descriptive analysis. The research findings show teachers have a positive perception of ERT implementation. Teachers have tools that can support ERT implementation, and in its implementation, the teacher has tried to provide authentic and various learning material. There are differences in perceptions between teachers and students. Students have negative perceptions of the implementation of ERT. They are hampered by lack of access to the internet so that they are not able to fully participate in ERT. The difference in perception can also be seen from the learning material. Students feel that the material provided by the teacher are difficult to understand. The challenges faced by teachers and students in general are technical challenges, teaching and learning instructions, and pedagogical challenges. However, ERT has not been maximally implemented due to several factors.

\section{Keywords: Emergency Remote Teaching; Perception; Teaching and Learning}

\section{INTRODUCTION}

At the end of 2019 and beginning of 2020, corona virus has changed many aspects of human life including industry, economics and even education. Learning that is usually done at school, now turns into online-based learning in order to implement social and physical distancing due to the COVID-19 outbreak. Teachers and students no longer come to school to do the learning process, but they do it at home with the help of platforms that support this process. Hodges, Moore, Lockee, Trust, and Bond (2020) use the term emergency remote teaching to adjust the appropriate terminology for this pandemic condition. The teacher and students are in different places in this situation, in their respective homes in the learning process. In the application of online learning, there are certainly many challenges experienced by students and teachers. Especially for those who have never applied this learning model before.

\section{RESEARCH METHOD}

Mix-metode design was carried out in order to gather the data. A mixed - method design is a procedure for collecting, analyzing, and mixing both quantitative and qualitative method in a single study or a series of studies to understand a research problem (Cresswell, 2012). The population in this study was the English teachers and grade 11th students in Bangli. The questionnaire was used to identify the perception EFL teachers and students towards Emergency Remote Teaching (ERT), which was gathered by 110 students and 30 English teachers and delivered through google form. The interview and online observation were conducted to identify the implementation of ERT. The interview was semi-structured interview conducted conversationally with the respondent at a time, the SSI employed a blend of closed- and open-ended questions, often accompanied by follow-up why or how 
questions (Adams, 2015). It was carried out with 5 English teachers and students through telephone. The online observations were conducted for one month.

To analyze the data from questionnaire, this study used central tendency and variability. The central tendency analysis seeked the mean score and the variability seeked the standard deviation. The data from the interview were analyzed with guidance of analyzing qualitative data by O'Connor and Gibson (2003). Meanwhile the online observation was analyzed by descriptive analysis.

\section{FINDINGS AND DISCUSSION}

After collecting and analyzing the data, the teachers' responses towards the implementation of emergency remote teaching and learning in EFL were identified. The result of data analysis was presented from each dimension of questionnaire which was developed by Alam, Waqar, Zaman, and Mehmood (2012); Bhaumik and Priyadarshini (2020); Kintu and Wanami (2019) and Totaro, Tanner, Noser, Fitzgerald, \& Birch, 2005) which was divided into access, teaching material, experience and teacher preferences, as follows:

Table 1. Teachers' Perception towards ERT

\begin{tabular}{|c|c|c|c|c|c|}
\hline Dimension & & Frequency & Percent & Mean Score & $\begin{array}{l}\text { Standard } \\
\text { Deviation }\end{array}$ \\
\hline \multirow[t]{5}{*}{ Access } & $\begin{array}{l}\text { Very } \\
\text { Neqative }\end{array}$ & 1 & 3.3 & & \\
\hline & Negative & 1 & 3.3 & 4.60 & .968 \\
\hline & Neutral & 1 & 3.3 & & \\
\hline & Positive & 3 & 10.0 & & \\
\hline & Very Positive & 24 & 80 & & \\
\hline Teaching & Negative & 1 & 3.3 & & \\
\hline \multirow[t]{2}{*}{ Material } & Positive & 1 & 3.3 & 4.86 & .571 \\
\hline & Very Positive & 28 & 93.3 & & \\
\hline \multirow[t]{4}{*}{ Experience } & Very & 3 & 10.0 & & \\
\hline & Negative & & & 2.16 & .592 \\
\hline & Negative & 19 & 63.3 & & \\
\hline & Neutral & 8 & 26.7 & & \\
\hline Teachers' & Very & 8 & 26.7 & & \\
\hline \multirow[t]{5}{*}{ Preference } & Negative & & & & \\
\hline & Negative & 11 & 36.7 & 2.56 & 1.430 \\
\hline & Neutral & 1 & 3.3 & & \\
\hline & Positive & 6 & 20.0 & & \\
\hline & Very Positive & 4 & 13.3 & & \\
\hline
\end{tabular}

There were 30 English teachers answered the questionnaire. The result from Table 1 indicates the teachers have access to conduct remote teaching such as gadget, smartphone or pc. This finding was also supported by the result of telephone interview. In the interview, the teachers said

For online teaching support tools, I have no problem. (T1)

I have a cellphone or laptop, but sometimes the problem is on the internet network. (T2)

It can be said that the teacher has access to implement remote teaching. With this access, it makes it easier for teachers to teach in a pandemic situation. However, teachers also realized that sometimes a slow internet network can hinder the teaching process. The second dimension is teaching material. This dimension deals content of teaching material provided to the students during ERT. Based on the mean score in Table 1, it falls to very positive perception. This means that the teachers perceived that they gave learning material that is motivating, interesting and varied. In the interview, the teachers said: 
Learning material must attract students' interest in learning. So that students really learn and not just play games. (T2)

I try to provide a variety of materials so that students do not get bored of learning from home. (T3)

From the results of the interview, the teacher said that they had provided teaching material that could help students while studying from home. The third dimension of the questionnaire was teachers' experience during remote teaching. Experience dealt with how ERT affected teachers' teaching experience including there were or not any difficulties during the ERT implemention, and how teaching and learning process was carried out. This indicates that the teachers were experiencing difficulties during remote teaching. In the interview, the teacher said:

Honestly, because this is my first experience teaching online. the difficulty is how to make learning instructions. I realized that the learning I was doing was monotonous, so it was natural for students to start getting bored. (T4)

There are several problems both technically and non-technically. For technical matters, the problem is the internet. The non-technical problem is making learning planning, continuing its application and problems regarding assessment. (T2)

I have never given a training how to teach online before. But, the school asked us to attend a training when there is webinar provided by university. (T1)

From the interview results, the teacher explained that they experienced problems during the remote teaching process. Based on the mean score in Table 1 (2.56), it falls to negative perception. The result of interview also revealed teachers' preference of face to face especially in vocational school. In the interview, the teacher said:

I prefer face to face, because I teach at Vocational School, especially for $11^{\text {th }}$ graders, most of them are assigned to productive lessons, and soon doing work-practice, so it might be more effective if they learn in face to face. (T1)

If this pandemic is over, it is certain to learn face to face, especially vocational schools, there are many practices, it is very difficult to teach practice online. (T3)

The teacher's response stated that they prefer face to face teaching. Moreover, in the context of SMK, vocational school students are required to practice before their internship. On the other hand, students have different perception about Emergency Remote Teaching. The result of 110 students through online questionnaire is presented in Table 2.

Table 2. Students' Perception towards ERT

\begin{tabular}{llcccc}
\hline Dimensions & Frequency & Percent & Mean Score & $\begin{array}{c}\text { Standard } \\
\text { Deviation }\end{array}$ \\
\hline Accesss & Very Negative & 16 & 14.5 & & \\
& Negative & 44 & 40.0 & & \\
& Neutral & 32 & 29.1 & 2.51 & 1.029 \\
& Positive & 13 & 11.8 & & \\
Learning & Very Positive & 5 & 4.5 & & \\
Materials & Very Negative & 13 & 11.8 & & .881 \\
& Negative & 51 & 46.4 & & \\
& Neutral & 36 & 32.7 & 2.41 & \\
& Positive & 7 & 6.4 & & \\
\hline
\end{tabular}




\begin{tabular}{llcccc}
\hline & Very Positive & 3 & 2.7 & & \\
Support & Very Negative & 19 & 17.3 & & \\
System & Negative & 27 & 24.5 & & \\
& Neutral & 46 & 41.8 & 2.59 & .889 \\
& Positive & 16 & 14.5 & & \\
& Very Positive & 2 & 1.8 & & \\
\hline
\end{tabular}

There were 110 students responded the questionnaire. The result from Table 2 indicates that there are students who are not able to follow or access instruction in emergency remote teaching because they do not possess the supported tools such as gadget, smartphone or PC. This was also supported from the interview with students

The internet connection is bad at home. Sometimes I can't join Zoom clearly just because of the connection. (S1)

Often I am late for assignments because there is no connection. there is no Wi-Fi at home (S2)

From the results of the questionnaires, it can be said that students have difficulty accessing learning content in ERT. Even though they have the tools to perform ERT, but poor network connections become an obstacle to the learning process.

The second dimension is learning material. Based on Table 2, it is proved that the students see the learning material are difficult to understand, unmotivating, and not interesting. This was also supported from the interview with students.

Sometimes, the materials are difficult to understand especially from the text book source. But when the teacher gave a video / tutorial it is easier to understand (S1)

Judging from the results of the student and teacher questionnaire analysis of the learning material, it can be seen that the difference is quite clear. Teachers have positive perceptions while students have negative perceptions of learning material. This imbalance may occur because the teacher feels that they have provided the appropriate material, but students' abilities are still limited in understanding the material. The teacher's absence directly can be a factor that hinders students from understanding the teaching material because students are used to getting direct explanations from the teacher.

The third dimension is support system. This dimension deals with the support that the students possess in following the remote teaching. The data in Table 2 indicates that the students have negative perception towards support system. This happened because the students see the teachers are lack of explanation during remote teaching, give difficult task or the teachers lack of knowledge to implement remote teaching. In the interview, the students said:

Sometimes the teacher provides learning material without providing an explanation. (S2)

There are teachers who only ask us to summarize the learning material and answer the questions given (S3)

From the students' responses, it can be said that in remote teaching learning, the teacher is passive. The students see the discussion in remote teaching rarely happened. The activities in remote teaching is dominantly filled with summarizing and answering questions.

The fourth dimension of the questionnaire was the students' preference in learning. The students were asked whether they prefer face to face or online learning. The result is presented in Table 3. 
Table 3. Students' Preference

\begin{tabular}{lll}
\hline & Frequency & Percent \\
\hline Face To Face & 103 & 93.6 \\
Remote Teaching & 7 & 6.4 \\
Total & 110 & 100.0 \\
\hline
\end{tabular}

From Table 3, it can be seen that the students who prefer face to face is $93.6 \%$ while those who prefer online is $6.4 \%$. This indicates that the students dominantly prefer to learn in face to face setting. The interview also revealed that the students prefer face to face instead online. As they say

\section{I am more comfortable learning face to face, understand more quickly (S2)}

For now, it is online teaching because of corona virus. but hopefully in the near future, we come back face to face (S4)

Although students prefer face-to-face learning, in this pandemic condition, students feel that online teaching is the most appropriate. Learning is currently still being recognized online for health reasons.

In identifying the teaching activities in ERT setting, observations and interview were conducted. The implementation observations including the preparation, action until assessment. The finding is presented into four dimensions which were developed by Shi, Xie, and Xu (2003), Perveen (2016), Wang and Wiesemes, (2016) and Zayapragassarazan (2020) , which were divided into four components they are model, platform, media and assessment.

From the result of observation, teachers conducted the teaching using synchronous and asynchronous model. However, it was observed that the asynchronous teaching was more frequently used by teachers. Learning is not fully carried out through zoom or google meet because the teacher is aware of the technical problems faced by students. In the interview the teacher said;

I use WhatsApp more often than zoom to teach. So face to face with Zoom it's possible only once a month. (T2)

The media applied by teachers were online textbooks, YouTube videos, and web. For the assessment, it was identified that the teachers assigned the students to create video related with the learning material and also supported by the data from interview and online observation. In Interview, teacher said:

Sometimes I take the material from YouTube to make it easier for students to understand with the visualization. You can also teach listening skills. (T4)

For the assessment, I usually tell them to make a project. For example, make a summary about the material with a video presentation. (T1)

This study also found that there were several challenges faced by teachers and students during ERT. The first challenge is a network connection problem. Teachers and students convey that bad networks always affect the teaching and learning process, especially for students. Due to network problems, students are often late in collecting assignments and sometimes do not attend during the learning process either with WhatsApp or Zoom. Several previous studies have also found connection problems to be a barrier to online teaching and learning (Gillett-swan, 2017; Kebritchi et al., 2017; Mishra et al., 2020). Unlucky, there is nothing that teachers and students can do if technical problem like this occurs during ERT.

Instructional challenges were also found in this study. Teachers realize that they are not maximum in designing learning because they did not have experience in teaching online. They also conveyed that they had never attended online teaching training. 


\section{CONCLUSION AND SUGGESTIONS}

From the findings of the study obtained, there are four conclusions can be explained that teachers have a positive perception of ERT implementation. Teachers have tools that can assist ERT implementation and are able to use them. In its implementation, the teacher has tried to provide authentic learning material so that students have no difficulty in learning. There are differences in perceptions between teachers and students. Students have negative perceptions of the implementation of ERT. They are hampered by lack of access to the internet so that they are not able to fully participate in ERT. The difference in perception can also be seen from the learning material. Students feel that the material provided by the teacher is difficult to understand. This is because teachers do not provide explanations and they find it difficult to ask the teacher questions because of limited internet access.

Teachers and students agree that they prefer to study face-to-face. Although this can be overcome by using Zoom, students have limited internet access again, so they are often absent during Zoom meetings. Even so, teachers and students are well aware that health is the top priority so that teachers and students can do their best to maximize ERT. The challenges faced by teachers and students in general are technical challenges.

The suggestions in this study are addressed to English teachers that English teachers are advised to consult ERT with peers or experts. In the future, English teachers are also advised to actively participate in online teaching trainings provided by universities or related institutions

\section{ACKNOWLEDGMENT}

The writer would like to express sincere gratitude to people who gave worth assistance, guidance, suggestion, and support for the accomplishment of this study. They are Made Hery Santosa, Ph.D and Dr. Dewa Putu Ramendra, S.Pd., M.Pd who kindly gave valuable motivation, idea, advise, suggestion, and guidance in accomplishing this study.

\section{REFERENCES}

Adams, W. (2015). Conducting Semi-Structured Interviews. In K. Newcomer, H. Hatry, \& J. Wholey (Eds.), Handbook of Practical Program Evaluation (Issue August). JosseyBass. https://doi.org/10.1002/9781119171386.ch19

Alam, Z., Waqar, A., Zaman, K., \& Mehmood, Y. (2012). Perception of Students towards Distance Learning: A Case Study of Pakistan. Journal of American Science, 8(11), 509-517.

Bhaumik, R., \& Priyadarshini, A. (2020). E-readiness of senior secondary school learners to online learning transition amid COVID-19 lockdown. Asian Journal of Distance Education, 15(1), 244-256.

Cresswell, J. W. (2012). Educational Research. Pearson.

Gillett-swan, J. (2017). Th e Challenges of Online Learning Supporting and Engaging the Isolated Learner. Journal of Learning Design, 10(1), 20-30.

Hodges, C., Moore, S., Lockee, B., Trust, T., \& Bond, A. (2020). The Difference Between Emergency Remote Teaching and Online Learning. Creative Commons BY-NC-ND 4.0 International License.

Kebritchi, M., Lipschuetz, A., \& Santiague, L. (2017). Issues and Challenges for Teaching Successful Online Courses in Higher Education. Journal of Educational Technology Systems, 46(1), 4-29. https://doi.org/10.1177/0047239516661713

Kintu, D., \& Wanami, S. (2019). Students 'perceptions about a distance learning programme: A case of the open, distance and E-learning programme at. International Journal of Advance Research, Ideas and Innovations in Technology, 5(1), 388-394.

Mishra, L., Gupta, T., \& Shree, A. (2020). Online teaching-learning in higher education during lockdown period of COVID-19 pandemic. International Journal of Educational Research Open, 1(August), 100012. https://doi.org/10.1016/j.ijedro.2020.100012 
O'Connor, H., \& Gibson, N. (2003). A Step-by-Step Guide to Qualitative Data Analysis. A Journal of Aboriginal and Indigenous Community Health, 1(1), 64-90.

Perveen, A. (2016). Synchronous and Asynchronous E-Language Learning: A Case Study of Virtual University of Pakistan. Open Praxis, 8(1), 21-39.

Shi, Y., Xie, W., \& Xu, G. (2003). Smart Remote Classroom : Creating a Revolutionary RealTime Interactive Distance Learning System. Advances in Web-Based Learning: First International Conference, 1-10. https://doi.org/10.1007/3-540-45689-9

Totaro, M. W., Tanner, J. R., Noser, T., Fitzgerald, J. F., \& Birch, R. (2005). Faculty Perceptions Of Distance Education Courses: A Survey. Journal of College Teaching \& Learning, 2(7), 13-20.

Wang, R., \& Wiesemes, R. (2012). Enabling and supporting remote classroom teaching observation: live video conferencing uses in initial teacher education. Technology, Pedagogy and Education, 21(3), 351-360. https://doi.org/10.1080/1475939X.2012.719397

Zayapragassarazan, Z. (2020). COVID-19: Strategies for Online Engagement of Remote Learners. https://doi.org/10.7490/f1000research.1117835.1 